\title{
Behavior of Assets Disclosure of Personal Tax Payers on Following Tax Amnesty Program (Phenomenology Study)
}

\author{
Yustina Wahyu Dwijayanti, Hamidah \\ Indonesia
}

*Corresponding Author: Yustina Wahyu Dwijayanti, Hamidah, Indonesia

\begin{abstract}
:
Objective - This study aims to reveal what lies behind the individual taxpayers participating in the tax amnesty program and how the disclosure of personal assets taxpayers' behavior enters the tax amnesty program.

Design / Methodology / Approach - Research is a qualitative research with phenomenological methods. Phenomenology aims to find out the world from the point of view of a person who experiences directly or is related to the nature of human experience, and the meaning that is attached to him. This study uses a semistructured interview method.

Results - The results of the study prove that the entrepreneurs did not disclose all their assets in the tax amnesty program because the informants were not sure of the government's control after the tax amnesty. UMKM taxpayers follow tax amnesty by revealing all their assets because of subjective norms, namely the direction of their tax consultants which explains that going forward will enter an era of openness. Tax consultants report all of their assets in the tax amnesty program because of their attitude which is shaped by their experience and knowledge. They believe that after the tax amnesty program the government will enter Automatic Exchange of Information (AEOI) where taxpayers cannot hide their property anymore.
\end{abstract}

Authenticity / Value - Research uses the Theory of Planned Behavior (TPB) to examine how the disclosure behavior of individual taxpayers' assets in participating in tax amnesty.

Keywords: Tax Amnesty, Assets Disclosure, Phenomenology, Theory of Planned Behavior (TPB)

\section{Preliminary}

Tax amnesty is a large government program in obtaining tax revenue. Considering tax revenues always do not reach the target that has been determined. The tax amnesty program has been planned by President Joko Widodo which will begin on July 1, 2016, but socialization has been carried out directly to Taxpayers to all regions in Indonesia before July 1, 2016. Tax revenues have an important role for a country, especially used to build infrastructure, health, education, and much more. Several policies and programs were launched by the government in relation to safeguarding the achievement of revenue and taxation targets in particular. One of them is the tax amnesty program. The enactment of the tax amnesty program is expected to cover shortages of funds in the short term and can increase public compliance with taxes in the long term.

The main purpose of tax amnesty is to re-enter their investment to Indonesian or funds owned by Indonesians stored abroad. Funds that have been repatriated domestically will be used to support economic growth. 2018 is the year when Indonesia will enter the era of information disclosure. In preparing this matter the government issued a tax amnesty law. If the era of information disclosure has been running later in the next few years, the boundaries between countries have not become obstacles, including tax information. The hope of the government with this program is that taxpayers report their assets transparently so the government has a taxation database.

Tatiana and Priyo (2009), Mira (2010), Monica (2011) provide that sunset policy results have a positive influence on taxpayer compliance. But the results of research by Widi and Bambang (2011) showed a different results, sunset policy had no effect on tax compliance reasons. Sunset policy is one of the government's major programs in the field of taxation as well as tax amnesty. The difference 
between these results shows that the awareness of the Indonesian people's tax payments has not been evenly distributed.

The government's target for tax revenue from the tax amnesty program is Rp 165 trillion. Although at the end of the tax amnesty period the target is not achieved, the government believes that the tax base obtained from the tax amnesty program will increase state revenues in the future. The realization of this program's revenue only reached Rp.114 trillion, far below the target set by the government of Rp165 trillion.

The profits received by taxpayers if they take part in the tax amnesty program is enough to make the taxpayer moved to join this program. This benefit greatly influences the reason or behavior of taxpayers to take part in the tax amnesty program. However, taxpayers also have their own interests and reasons why choosing to join the tax amnesty program. The existence of differences in interests above makes researchers want to examine what is actually behind the behavior of taxpayers to take part in the tax amnesty program.

This study uses the Theory of Planned Behavior (TPB) as a basis theory for analyzing the behavior of taxpayers in their participating in the tax amnesty program. Based on the Theory of Planned Behavior, the reason for behaving is determined by 3 determinants, namely behavioral beliefs, normative beliefs and control beliefs. Behavioral beliefs are defined that behaviors based on an individual's belief in that and evaluation of the results of that behavior. The second factor is Normative beliefs. Normative beliefs are beliefs about normative expectations of other people around them who have an influence on them and motivation to meet that person's expectations. The third factor is control beliefs. Control beliefs mean someone's belief about things that support or inhibit the behavior that will be done and their perceptions and beliefs about how strong it can support and inhibit the behavior (power of control factor).

In this study, researchers will use qualitative research methods with interpretive paradigms with phenomenological approaches. The interpretive paradigm emphasizes more on one's meaning or interpretation of a symbol. Burrell and Morgan (1979: 20) describe the interpretive nature as a paradigm that has characteristics to understand and explain the social world that is inseparable from personal glasses that are directly involved in a social process. Researchers use a phenomenological approach because this method can reflect a person's direct experience, insofar as that experience is intensively related to an object (Kuswarno, 2009: 1). Phenomenology can find answers about the meaning of a phenomenon. Researchers want to understand and explain what is the reason for an individual taxpayer's behavior in participating in the tax amnesty program viewed from the person's perspective on tax amnesty, the influence of people around him and factors that hinder or support the decision of taxpayers in the tax amnesty program.

Researcher is focus to a personal taxpayer experience. The aim of the researcher to choose a personal taxpayers because the government's target in this program besides that personal taxpayers are considered to be more able to provide a deeper explanation of their experience and reasons for participating in tax amnesty than corporate taxpayers. Where the corporate taxpayer in taking a decision is determined by many parties who have the authority of each.

Based on the description above, this research will reveal what lies behind the individual taxpayers participating in the tax amnesty program and how individual taxpayers behave in participating in the tax amnesty program.

\section{LITERATURE REVIEW}

\subsection{Tax Amnesty}

Tax amnesty is a tax abolition program that should be owed, but will not be subject to tax administration sanctions and criminal sanctions in the field of taxation. This is done by revealing assets and paying ransoms. Taxpayers are expected to participate in the tax amnesty program by paying ransoms calculated from additional assets reported in the Surat Pernyataan Harta (SPH). If administrative requirements have been declared complete, the taxpayer will get a Surat Keterangan. Taxpayers who have issued a Surat Keterangan get a tax amnesty facility (a) removal of tax payable that has not been issued tax assessment, not subject to tax administration sanctions, and not subject to criminal sanctions in the field of taxation, for tax obligations in the tax period, part of the tax year and 
tax year, until the end of the last tax year. (b) Elimination of tax administration sanctions in the form of interest, or fines, for tax obligations in the tax period, part of the tax year, and tax year, until the end of the last tax year. (c) No tax audit, preliminary proof of examination, and taxation in the field of taxation, tax obligations in the tax period, part of the tax year, and tax year, until the end of the last tax year and (d) termination of tax audit, inspection preliminary evidence, and taxation criminal investigation, in the case of a taxpayer being carried out a tax audit, examination of preliminary evidence, and taxation criminal investigation of tax obligations, until the end of the last tax year.

Behind the benefits provided by the government, there are substantial sanctions if the taxpayer just follows the tax amnesty but does not report all the assets he owns. Pursuant to Law number 11 of 2016 article 8, in the event that the taxpayer has obtained a Surat Keterangan then found data and / or information concerning a that have not been or have not been disclosed in the Surat Pernyataan Harta the assets are deemed as additional income received or obtained by mandatory taxes when data and/or information about assets are discovered will be subject to income tax in accordance with the provisions of the legislation in the field of income tax plus tax administration sanctions in the form of an increase of $200 \%$ of income tax that is not or less paid.

\subsection{Theory of Planned Behavior (TPB)}

This theory provides a framework for studying attitudes towards behavior. Based on this theory, the most important determinant of a person's behavior is the intention to behave. Individual intention to display a behavior is a combination of attitude toward the behavior, subjective norm, and perceived behavioral control.

The concept or the forming factors in the Theory of Planned Behavior include:

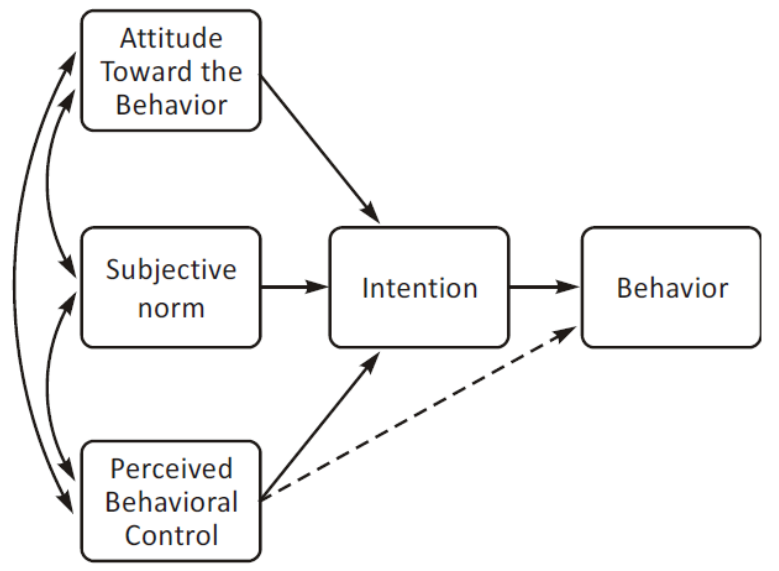

Figure1. Theory of Planned Behavior

(Source Ajzen, 2005: 118)

\subsubsection{Attitude towards the Behavior (Attitude)}

Ajzen (2005) suggests that attitudes toward this behavior are determined by beliefs about the consequences of a behavior or briefly called behavioral beliefs. Beliefs related to the subjective judgments of individuals towards the world around them, individual understanding of themselves and their environment, is done by connecting between certain behaviors with various benefits or losses that may be obtained if the individual does or does not do so.

\subsubsection{Subjective Norm (Subjective Norm)}

Subjective norms are individual perceptions of the expectations of influential people in their lives (significant others) regarding the conduct or failure of certain behaviors.

\subsubsection{Perceived Behavioral Control (Perception of Behavior Control)}

Perception of behavioral control or can be called behavior control is an individual's perception of the ease or difficulty of realizing a certain behavior. In TPB, Ajzen (2005) argues that the perception of behavioral control is determined by individual beliefs about the availability of resources in the form of equipment, compatibility, competency, and opportunity (control belief strength) that support or inhibit 
the behavior that will be predicted and the magnitude of the role of these resources (power of control factor) in realizing this behavior.

Endang's (2015) research results in which three factors that determine a person's reason for behaving according to the Theory of Planned Behavior, namely attitudes, subjective norms and perceptions of behavioral control have a positive influence on the reasons for disobedience. Alrisa (2014), the lack of intentions of taxpayers to pay taxes is because many taxpayers feel that they pay complicated taxes, lack of knowledge about taxation, frequent changes in regulations without clear socialization, paying taxes is still burdensome for them because the tariffs are still considered too high, and a lot of tax fraud by the government.

Different research results in Theresia's (2012) study where attitudes, subjective norms and behavioral control perceptions had a positive influence on the reasons for complying with tax regulations. Erwin (2009) there are several other factors that influence taxpayer compliance are the financial condition of the company, the condition of the company's facilities and the company's climate affect the reasons for compliance while the control perception of tax professional behavior only has a small effect on the reasons for behaving obediently in carrying out its tax obligations. While Widi's research (2011) states that only subjective norms do not affect the reasons for behaving obediently.

This research originated from the existence of a phenomenon where the target of tax revenue from the tax amnesty program was not achieved. The government's target for tax revenue from the tax amnesty program is Rp. 165 trillion, but at the end of the tax amnesty period, the incoming revenues only reach Rp. 114 trillion. Then the question arises how is the behavior of taxpayers in participating in the tax amnesty program and what is the reason for individual taxpayers in participating in the tax amnesty program. This is to see whether the failure to achieve the target of tax amnesty is caused by the behavior of taxpayers in participating in the tax amnesty program.

\section{RESEARCH METHODS}

This research is a qualitative research. The research aims to understand reality more deeply, have a subjective perspective, and build theory based on inductive logic. This research was conducted with phenomenology method. Phenomenology will explore data to find the meaning of basic and essential things from the phenomenon, reality, or experience experienced by the object of research. Phenomenology aims to find out the world from the point of view of people who experience directly or relate to the natural traits of human experience, and the meaning that is attached to it (Kuswarno, 2009: 35).

In this study, researchers dig information about how taxpayer behavior in participating in the tax amnesty program is based on the Theory of Planned Behavior. Researchers must understand deeply about the object of research including the rules regarding tax amnesty so that they can explore information from informants in depth and detail. In particular, researchers must dig up information on what constitutes informants' behavior in following the Indonesian government's major program in taxation, namely tax amnesty.

The type of data used in this study is primary data and secondary data. Primary data is data derived directly from the source of data collected specifically and directly related. Primary data is obtained by interviewing nine individual taxpayers who take the tax amnesty program which are grouped into three categories.

- Three individual taxpayers who work as tax consultants.

- Three individual taxpayers as UMKM.

- Three individual taxpayers as entrepreneurs

In addition to conducting interviews, researchers will also use secondary data to ensure the validity of the interview results. Secondary data is data in the form of Surat Penyataan Harta (SPH) from each individual, documents such as tax regulations, supporting documents in the preparation of SPH and the news contained in print and online media. Triangulation is the technique of checking the validity of data that utilizes something other than that data for checking purposes or as a comparison of the data (Lexy J. Moleong, 2007: 330). Triangulation used in this research is source triangulation. Triangulation with sources means comparing and checking the degree of trust of information obtained 
through different time and tools in qualitative research. Source triangulation in this study was carried out by comparing data obtained through interviews and documentation.

\section{EMPIRICAL RESULTS}

Tax amnesty is the first step taken by the government in implementing an automatic exchange of information / AEOI policy. Countries that will join in AEOI will send and receive initial information every year without having to submit a special request. Before financial transparency really happens, a country is advised to do tax amnesty to all its citizens. Through tax amnesty, the government provides tax amnesty for taxpayers who have not reported all the assets they have had.

\subsection{UMKM Taxpayers}

The enthusiasm of taxpayers in participating in tax amnesty is quite large. Both big businessmen and UMKM are also trying to find out what this tax amnesty really is. UMKM are groups of taxpayers who have great potential even though they are not the main target of this program. The large potential tax revenue from UMKM can be seen from the contribution of UMKM to Gross Domestic Product (GDP) recorded at $61.41 \%$. Based on the Theory of Planned Behavior, attitudes are determined by beliefs about the consequences of a behavior or briefly called behavioral beliefs. Based on interviews with UMKM taxpayers, they have very little knowledge and experience regarding tax amnesty. This lack of knowledge and experience influences the taxpayer's belief in their behavior. At the beginning of hearing about the tax amnesty program, these UMKM taxpayers did not have the intention to attend the tax amnesty. Taxpayers can get information from KPP socialization and also from mass media and even social media such as Instagram. But for UMKM taxpayers this is not enough to convince them whether they have to attend tax amnesty or not. This means that the experience and knowledge of UMKM taxpayers do not have the strength in the behavior of these UMKM taxpayers.

UMKM taxpayers see that this tax amnesty is a program where they can disclose assets that have not been reported must be reported (noema). In the tax amnesty program, the government has a future goal, so that taxpayers or traders who have not reported the tax will be more orderly to report the tax, especially now that the government is given the ease with the tax amnesty program (noesis). Many taxpayers take part in tax amnesty because the ransom rates that must be paid are quite small compared to the facilities provided.

Subjective norms are individual perceptions of the expectations of influential people in their lives. Based on the results of interviews the role of tax consultants is very large in directing UMKM taxpayers to participate in the tax amnesty program. The explanation from the tax consultant is the biggest influence for informants to take part in tax amnesty by revealing all their assets in tax amnesty. This is consistent with the results of Ramayah et al. (2009), where subjective norms will have the most important effect on users who have no experience.

Three taxpayers interviewed, they revealed that based on the explanation from their tax consultants that through this tax amnesty the government was preparing Indonesian to entering the era of openness. Where later all information can be accessed across the country so that if assets are found that have not been reported by the government, they will provide a large fine of $200 \%$ of the underpaid tax. The magnitude of these sanctions causes UMKM taxpayers to be afraid to hide their property because it will disrupt their business.

After this tax amnesty program, the government will further strengthen their supervision of all taxpayers. This is also the biggest consideration by informants when they take part in tax amnesty by reporting all their assets. Informants feel that the government will get stronger after the tax amnesty program. The report of post tax amnesty for the next three years is also considered by the government as a strong dick. In addition, almost all tax programs currently use online technology so that it will be easier to carry out full supervision. One of the informants, Mrs. E revealed that the presidential administration of Jokowi, Indonesia had experienced enough progress in the field of taxation.

UMKM informants assume that this program is actually intended not for them but for large traders and taxpayers who have assets abroad. But because the tarif is cheap they choose to disclose all their assets so they are no longer "hidden" with the KPP officers. They feel afraid that if they find a treasure that has not been reported and are subject to such sanctions, it will cause their business to go 
bankrupt. The informant hopes that after this tax amnesty program the government must firmly implement the sanctions so that taxpayers who have revealed all their assets do not feel disappointed.

"Yes, the hope is that we are honest, I have reported what it is and so on. Yes, the hope might be that those who did not participate or maybe those who were obeyed yesterday were not reported on their assets. Yes, the sanctions should be applied. So, for those who are really honest, it will be fine. Who joined or not, obeyed the same thing that didn't make any difference." (Mrs. L)

\subsection{Entrepreneurs Taxpayers}

President Jokowi says that the main target for the implementation of tax amnesty policy is a large taxpayers who put their money abroad. Where is the big entrepreneur who can own assets abroad. The government's goal is to "repatriate" these funds to Indonesia so that they can be used to support Indonesia's economy and development. The three informants have an opinion that tax amnesty is a good program so when the Tax Amnesty Act is socialized, entrepreneurs have intended to attend the tax amnesty. But entrepreneurs have other views on tax amnesty. In accordance with TPB, beliefs and evaluations can shape attitudes towards certain behaviors in this case the behavior of participating in tax amnesty.

Of the three informants interviewed, two of them still chose not to report all their assets because they felt the government was only looking for additional tax revenues because of chasing targets. Besides that, a lot of corruption or fraud makes entrepreneurs more reluctant to pay taxes. This is in accordance with Cahyani (2014), that non-compliance is caused by their lack of knowledge about taxation and the belief in the existence of tax fraud by the government. The entrepreneurs do not understand the tax amnesty rules in depth. They only understand that in this tax amnesty they can disclose assets that have not been reported by paying a ransom then the previous year's report is deemed clear as stated by Mr. H:

"In my opinion, in the Law on Tax Amnesty, he says that the tax sanctions are forgiven. Then

for our reports that were previously considered clear."

The informants obtained information about tax amnesty from their respective consultants. Most of them did not attend the socialization invitation from the Tax Service Office because they felt they already had a tax consultant. So the role of the tax consultant is also very large for the three informants in participating in the tax amnesty. They exchanged opinions with their consultants. But the direction of their consultants did not make them make the decision to reveal all the assets.

Mr. $\mathrm{H}$ and Mr. M still choose not to disclose all their assets because they feel the government's control after the tax amnesty program is not yet strong. They only follow the tax amnesty so that 2015 will not be checked and considered "clear". In the process of data triangulation through documentation, it was evident that Mr. H's assets in the form of a bank account still existed which had not been reported because a large enough mutation would cause a large VAT payment in 2016. Mr. H said the ransom rate was still quite expensive at $2 \%$ considering the current economy is decreasing, so $2 \%$ is too big.

"Looking for money 2\% is hard too, the economy is now more difficult. If the rate is smaller it might be able to (reveal all)." (Mr.H)

Even large sanctions are not their consideration when participating in tax amnesty. They say that sanctions are thought to be later important later they are participating in tax amnesty first. In addition, the two businessmen feel that the government's dick after tax amnesty is also not strong enough. This is because the government-owned human resources are not sufficient. In addition, the government does not have enough technology to control so many taxpayers. Mr. M said that business people are always looking for "jalan tikus" or loopholes in every regulation to remain safe in tax reporting. The entrepreneurs feel that the government itself is sometimes too oppressive and burdensome for entrepreneurs, so inevitably entrepreneurs also have to be smart to overcome the rules in taxation.

The factor that most influences the behavior of Mr. $\mathrm{M}$ and Mr. $\mathrm{H}$ who did not disclose all his assets was Perceived Behavioral Control whereby informants were not sure of the government's control after the tax amnesty. Mr. H explained that there are still many taxpayers who have not reported all of their assets in the tax amnesty program. This is because they lack trust in the government with a lot of criminal acts of corruption so they feel they are not yet willing to pay taxes. Informants hope the 
government must be firm. At present, Mr. $\mathrm{H}$ feels that the government is not strict with the new program, PAS FINAL. This is what keeps Mr. $\mathrm{H}$ still hiding assets in the form of deposits at one of the banks in Singapore and several vehicles that are still on behalf of his employees. According to the informant, if the tax authorities have found the data, they should immediately be dealt with firmly in accordance with the applicable sanctions rather than issuing a new program.

The different thing was expressed by Mrs. M even though was hesitant about the government's control after the tax amnesty would be strong, the informants still revealed all of their assets because the informants felt that they were going to retire so the informants did not want to burden their parents by feeling uneasy if there was assets that have not been reported. The informant also revealed that the Tax amnesty was better than the previous program and the tariff was cheaper.

"If I'm honest, I feel a little hesitant about it. I will soon want to retire, so if there is some data found, but I don't think everyone has been reported, so I am not afraid" (Mrs. M)

\subsection{Tax Consultant Taxpayers}

A tax consultant is a person whose scope of work is to provide professional services to taxpayers in carrying out their taxation rights and obligations in accordance with the applicable tax laws. Based on the results of an interview with Ms. A as a tax consultant she must continue to learn and understand what is contained in the tax amnesty law. According to Ms. A tax amnesty this is a pioneer (noema) of the progress of the tax program in Indonesia. This program is a program that is quite interesting because the incentives given with punishment are balanced (noesis). So the incentives are quite a lot and the punishment is quite large. The informants intend to attend the tax amnesty because this program has been anticipated by them because they have facilities that are large enough for personal informants or also for their clients when compared to the previous program.

Tax amnesty was launched by the government to face the era of openness going forward so that the government has a valid database of taxpayers in Indonesia. This database is the government's preparation to enter the era of AEOI (Automatic Exchange of Information). In addition, the government's goal is to increase taxpayer compliance so that it will increase tax revenues in the long run. The success of the tax amnesty program must be accompanied by the government's readiness to manage data that has been reported by taxpayers in tax amnesty. At present the government does not have a system that can once press the button all data will be open and integrated.

The government cooperates with the Indonesian Tax Consultants Association (IKPI) to socialize the Tax Amnesty policy to the entire community. The Indonesian Tax Consultant Association (IKPI) held a national seminar to disseminate the tax amnesty policy to all IKPI members throughout Indonesia. This seminar aims to enable all IKPI members to understand the tax amnesty policy properly, so that they can explain well to the taxpayers about the purpose of tax amnesty.

A new policy is always for IKPI members to take the time to attend seminars. This seminar serves to alternately exchange ideas and discuss where the government is going on, the impact and benefits of what tax amnesty is. Sometimes the same rules or laws but vary interpretations and perceptions. Through this seminar, tax consultants discussed with each other to equalize perceptions so that they can provide the best advice for clients.

Based on the Theory of Planned Behavior, confidence and evaluation will shape attitudes towards certain behaviors. The amount of knowledge and experience of the informants, they realize that the government will soon be open to enter the era of openness going forward. Therefore, the three informants stated implicitly that the informant reported all his assets because the informant knew that in the future the government would enter the era of information disclosure. The tax amnesty program will succeed if the government is supported by a good administrative system and taxation database and strict law enforcement.

Mrs. L added that the large sanctions were her consideration when she joined the tax amnesty. At present the government is starting to make improvements where all tax reporting systems have used technology in the form of programs and internet connections. According to Mrs. A, this would facilitate the control of tax officers against all taxpayers. Mrs. A said "In my opinion, it's not heavy because I already reported everything. No matter how much sanction it is, I just wait for the sanction". 
Based on the results of interviews with Mrs. A, the implementation of the tax amnesty was too hasty. Lack of socialization to all tax officers in the field caused obstacles in the implementation. Officers in the field also sometimes do not understand the correct procedure, causing confusion for taxpayers. This is what needs to be the material for DJP evaluation for the next program. But globally, Indonesia gets a thumbs up from other countries because this tax amnesty program is considered successful. But the informants hope the government must be consistent and firm in accordance with the Act that has been issued. Heavy punishments must be enforced so that taxpayers who have been "clear", who have reported all their assets do not feel disappointed so that the taxpayers returned do not pay all taxes that should be owed. In accordance with the research of Sutiono \& Mangoting (2015) trust in government has a significant effect on tax evasion practices. If confidence in the government gets better, then it can reduce tax evasion practices significantly.

\subsection{Not Achieving Tax Revenue Targets from the Tax Amnesty Program}

President Joko Widodo said that the main purpose of tax amnesty was to repatriate funds owned by Indonesians that were kept abroad owned by Indonesian taxpayers. Then the question arises who has funds abroad. Of course big taxpayers or big businessmen. From this it is clearly seen here that the target of this tax amnesty is businessmen or large taxpayers.

Tax amnesty is a program aimed at large payers who invest their assets abroad. However, based on this study, of the three informants, two of them did not disclose their assets in full for various reasons. One of them is because entrepreneurs still consider that this $2 \%$ ransom rate is still considered quite large. In addition they assume that government control after the tax amnesty program is not yet strong enough. Given the lack of technology and human resources who are skilled enough to control so many taxpayers. The entrepreneurs choose to still hide some of their assets while looking at whether the government will consistently implement sanctions in the future. Considering that all this time entrepreneurs have considered that the government tends to be less consistent with the programs offered by re-issuing similar new programs without following up on the old programs.

In contrast, in this study all informants who were UMKM taxpayers said that they had revealed all their assets. Based on the direction of their tax consultants, they believe that government control after the tax amnesty program will be strong enough. This is supported by the post TA report and the existence of several tax programs that have used an internet connection. They are afraid that if one day they find assets that have not been reported and are subject to sanctions of $200 \%$ it will disrupt their business continuity.

Based on the explanation above, it can be seen that the main target of this program is that large entrepreneurs do not report all their assets. It can be said that the main target of the government is not achieved or the government can be mistakenly targeted in this tax amnesty program. The government must evaluate this program to improve the next tax program. The government can provide "Shock Therapy" in the form of strict sanctions to large entrepreneurs who have not reported all their assets so that they will again believe in the government's consistency in sanctions and re-comply with the taxation rules.

In this study also found that age factors also affect taxpayers to obey the rules or not. One informant, Mrs. M explained that although she was hesitant about strong government control after the Tax amnesty program, she continued to report all her assets because she felt she was about to retire and had not wanted to be chased by tax officials if there were still assets being hidden. The same thing was revealed by the tax consultant informant Mrs. D.

"I am already old, so I just joined the government policy. It must be good that the government has policies, policies made."

This finding also strengthens previous research that age affects taxpayer compliance. Young taxpayers are more willing to take risks, less sensitive to punishment, while older taxpayers are usually more obedient than young ones (Sudiartana \& Mendra, 2017). In addition, Sutiono \& Mangoting (2015) concluded that age has a negative effect on tax evasion practices, this means that if the age gets younger, the practice of tax evasion is higher, or in other words, getting older made the more taxcompliant.

Based on the results of this study the role of tax consultants is so great for this tax amnesty program. In addition to providing guidance to clients to participate in tax amnesty, tax consultants also become 
tax amnesty program participants. The informants who work as tax consultants follow the tax amnesty by revealing all their assets. This is done to safeguard the tax consultant's code of ethics which is compliant with tax laws and regulations, and upholds the integrity, dignity and honor of the tax consultant profession. Integrity is the ability of people to realize what has been said or promised by a person becomes a reality. Based on research by Katuuk et al (2017) "Integrity of Tax Consultants has a partial effect on taxpayer compliance because in carrying out its duties as part of the government in collecting taxes from the public when properly and honestly carried out, it will encourage taxpayers as their clients to pay taxes correctly and honestly."

\section{CONCLUSIONS AND IMPLICATIONS}

\subsection{Discussion}

The main target of tax amnesty is to repatriate private funds invested abroad. However, of the three business informants, two of them did not disclose their assets as a whole. Both informants followed the tax amnesty because of the direction from their tax consultants. In addition, they also participated in the tax amnesty just to enjoy the facilities of the tax amnesty, namely free inspection. Based on the Theory of Planned Behavior, the strongest reason for the behavior of employers is the Perceived Behavioral Control where informants are not sure of the government's control after the tax amnesty. They feel the government controls after the tax amnesty is not strong because there is no technology that the government has to control taxpayers. However, one of the business informants said that although he was hesitant about the government's control after the tax amnesty program, he still reported his wealth as a whole because he felt was old so he did not want to "hidden" with tax officers.

On the contrary, all UMKM taxpayer informants reported their entire assets. The informants did not have enough knowledge about tax amnesty. They got directions from the Tax Service Office and from their consultants that the tax amnesty program was the first step the government entered into an era of openness. Informants believe that after this the government will immediately tighten rules and supervision. So they are afraid that if the government finds assets that have not been reported, the sanctions will be very large.

In this study subjective norms have the power to influence the behavior of UMKM taxpayers. In addition to subjective norms, large sanctions also become the background for UMKM to take full tax amnesty. The sanction will affect the sustainability of its business activities. So they choose to follow in full because the tariff is quite cheap while waiting for whether the government will implement the sanctions.

President Joko Widodo said that the main purpose of tax amnesty was to repatriate funds owned by Indonesians that were kept abroad owned by Indonesian taxpayers. Tax amnesty is a program aimed at large payers who invest their assets abroad. However, based on the results of this study, employers still have not reported all their assets, while UMKM taxpayers have reported all their assets. Tax amnesty has not made large taxpayers tax compliant.

In addition to these two categories of business actors, researchers also conducted interviews with tax consultants who participated in the tax amnesty program. Their experience and knowledge made them decide to take part in tax amnesty by revealing their overall assets. The informants have the view that this tax amnesty is a pioneer of the progress of the government tax program towards an era of openness. This tax amnesty is the initial step of the government to collect tax data databases for readiness to enter Automatic Exchange Of Information (AEOI). If this AEOI takes place, the information limit between countries is no longer available, so that if the assets that have not been reported are found, they will be subject to considerable sanctions, namely $200 \%$ of the tax that should be owed.

\subsection{Limitation and Future Research}

This research can be developed by adding one of the factors that influence taxpayer compliance, namely age. Where age will be able to determine the behavior of the taxpayer. Young taxpayers are more willing to take risks, less sensitive to punishment, while older taxpayers are usually more obedient than young ones (Sudiarto, 2017). In addition, further research can add other respondents who do not have tax consultants. So that it can be seen what actually affects the behavior of taxpayers in participating in tax amnesty even though taxpayers do not get direction from tax consultants. 


\section{REFERENCES}

[1] Achmat, Z. (2010). Theory of Planned Behavior, Masihkan Relevan. http://zakarija.staff.umm.ac.id/ files/ 2010/12/Theory-of-Planned-Behavior-Masihkah-relevan1. pdf. Diakses tanggal 08 Agustus 2017.

[2] Ajzen, I. (2005). Attitudes, Personality and Behavior, (2nd edition). Berkshire, UK: Open University Press-McGraw Hill Education.

[3] Ardani, M. N. (2010). Pengaruh Kebijakan Sunset Policy Terhadap Kepatuhan Wajib Pajak (Studi Kasus Di Kanwil Direktorat Jendertal Pajak Jawa Timur 1 Surabaya).Tesis. Universitas Diponegoro Semarang

[4] Burrell, G., \& Morgan, G. (1979). Sociological Analysis \& Organisational Analysis: Element of The Sociology of Corporate Life. London: Heinemann Educational Books.

[5] Cahyani, A. N. (2014). Perilaku Wajib Pajak Orang Pribadi di Bidang Perdagangan Untuk Membayar PPh Pasal 25/29 Dalam Tinjauan Planned Behavior of Theory (Studi Kasus pada KPP Pratama Ponorogo). Skripsi Jurusan Akutansi-Fakultas Ekonomi UM.

[6] Damayanti, T. W. (2012). Changes on Indonesia Tax Culture, Is there a way? Studies through theory of planned behavior. Researchers World, 3(4), 8-15.

[7] Darmayasa, I. N., \& Aneswari, Y. R. (2015). Paradigma Interpretif pada Penelitian Akuntansi Indonesia. Jurnal Akuntansi Multiparadigma, 6(3), 350-361.

[8] Dian, Monica. (2011). Pengaruh Pemanfaatan Fasilitas Perpajakan Sunset Policy Terhadap Tingkat Kepatuhan Wajib Pajak .Skripsi. Universitas Diponegoro Semarang.

[9] Ernawati, W. D., \& Purnomosidhi, B. (2010). Pengaruh sikap, norma subjektif, kontrol perilaku yang dipersepsikan dan sunset policy terhadap kepatuhan wajib pajak dengan niat sebagai variabel intervening. Jurnal Program Pasca Sarjana Magister Akuntansi Politeknik Negeri Malang dan Universitas Brawijaya.

[10] Harinurdin, E. (2011). Perilaku Kepatuhan Wajib Pajak Badan. BISNIS \& BIROKRASI: Jurnal Ilmu Administrasi dan Organisasi, 16(2).

[11] Hidayat, W., \& Nugroho, A. A. (2011). Studi empiris Theory of Planned Behavior dan pengaruh kewajiban moral pada perilaku ketidakpatuhan pajak wajib pajak orang pribadi. Jurnal Akuntansi dan Keuangan, 12(2), 82-93.

[12] Idris, M. (2016). 4 Tujuan Pemerintah Ingin Terapkan Tax amnesty. https://finance.detik.com/beritaekonomi-bisnis/3186301/4-tujuan-pemerintah-ingin-terapkan-tax-amnesty. Diakses tanggal 06 Juli 2018

[13] Katuuk, D., Manossoh, H., \& Walandouw, S. K. (2017). Pengaruh Integritas dan Kreativitas Konsultan Pajak Terhadap Kepatuhan Wajib Pajak. Jurnal Riset Akuntansi Going Concern, 12(2), 1-8.

[14] Kuswarno, E. (2009). Metodologi Penelitian Komunikasi Fenomenologi : Konsepsi, Pedoman dan Contoh Penelitian. Bandung: Widya Padjadjaran.

[15] Mustikasari, E. (2008). Kajian Empiris tentang Kepatuhan Wajib Pajak Badan di Perusahaan Industri Pengolahan di Surabaya. Simposium Nasional Akuntansi (SNA) X. Unhas Makasar. 26-28 Juli.

[16] Mutiah, M., Harwida, G. A., \& Kurniawan, F. A. (2011). Interpretasi Pajak dan Implikasinya Menurut Perspektif Wajib Pajak Usaha Mikro, Kecil dan Menengah. Jurnal Akuntansi Multiparadigma, 2(3), 418429.

[17] Moleong, L. J. (2007). Metodologi Penelitian Kualitatif. Bandung : PT Remaja Rosdakarya

[18] Rahmah, G. (2016). Ini Daftar 9 Profesi Prioritas Target Tax amnesty. https://bisnis.tempo.co/read/ 812338/ini-daftar-9-profesi-prioritas-target-taxamnesty\#yZ4QuBB02icJSKw5.99. Diakses tanggal 10 November 2017

[19] Ramayah, T., Yusoff, Y. M., Jamaludin, N., \& Ibrahim, A. (2009). Applying the Theory of Planned Behavi or (TPB) to predict internet tax filing intentions. International Journal of Management, 26(2), 272-284.

[20] Ramdhani, N. Penyusunan Alat Pengukur Berbasis Theory of Planned Behavior. Buletin Psikologi, 19(2), 55-69.

[21] Ratung, T., \& Adi, P. H. (2009). Dampak Program Sunset Policy Terhadap Faktor-Faktor yang Mempengaruhi Kemauan Membayar Pajak (Studi pada Wajib Pajak Orang Pribadi Pelaku Usaha di Wilayah KPP Pratama Salatiga).Universitas Kristen Satya Wacana Salatiga.

[22] Republik Indonesia. Undang-undang Nomor 11 Tahun 2016 Tentang Tax amnesty.

[23] Republik Indonesia. PER 11/PJ/2016. Pengaturan Lebih Lanjut Mengenai Pelaksanaan Undang-Undang Nomor 11 Tahun 2016 Tentang Tax amnesty.

[24] Sari, E. R. (2015). Pemahaman Wajib Pajak Atas Pemanfaatan Teknologi Pada Kantor Pelayanan Pajak Pratama Malang Utara (Tinjauan Berdasarkan Theory of Planned Behavior). Tugas Akhir Jurusan Akuntansi-Fakultas Ekonomi UM. 
[25] Sari, N. P. (2014). Pengaruh Penerapan e-SPT Terhadap Kepatuhan Wajib Pajak Badan Dalam Melaporkan SPT (Studi Kasus Pada KPP Madya Malang). Jurnal Mahasiswa Perpajakan, 2(1), 1-10.

[26] Sudiartana, I. M., \& Mendra, N. P. Y. (2017). Faktor-Faktor Yang Mempengaruhi Kepatuhan Wajib Pajak. Proceeding TEAM, 2, 184-195.

[27] Sugiono, A., Ludigdo, U., \& Baridwan, Z. (2015). Makna Pajak Dan Retribusi Perspektif Wajib Pajak Pedagang Kaki Lima. Jurnal Akuntansi Multiparadigma, 6(1), 53-78.

[28] Sugiyono. (2010). Metode Penelitian Pendidikan : PendekatanKuantitatif, Kualitatif, dan R\&D, cetakan kesebelas. Bandung : Alfabeta.

[29] Sutiono, M. A., \& Mangoting, Y. (2015). Pengaruh Pandangan Sosial, Usia, dan Kepercayaan Kepada Pemerintah Terhadap Praktik Penggelapan Pajak di Surabaya. Tax \& Accounting Review, 4(1), 261.

[30] Syakura, M. A., Khairin, F. N., Ginting, Y. L., Kusumawardani, A., \& Fitria, Y. (2016, May). A Behavioral Study on Voluntary Compliance of E-Commerce Tax. In ASEAN/Asian Academic Society International Conference Proceeding Series, 433-442.

[31] Winarsih, E. S. (2015). Faktor-Faktor yang Mempengaruhi Alasan Ketidakpatuhan Dalam Membayar Pajak (Studi Empiris Terhadap Wajib Pajak PBB-P2 Kabupaten Sukoharjo). MAGISTRA, 26(91), 8-20.

[32] www.finansialku.com. Setelah Amnesti Pajak Berakhir: Kehadiran AEOI (Automatic Exchange Of Information) di Indonesia. https://www.finansialku.com/setelah-amnesti-pajak-berakhir-kehadiran-aeoiautomatic-exchange-information-di-indonesia/. Diakses tanggal 5 Juni 2018

Citation: Yustina Wahyu Dwijayanti, Hamidah. "Behavior of Assets Disclosure of Personal Tax Payers on Following Tax Amnesty Program (Phenomenology Study)" International Journal of Managerial Studies and Research (IJMSR), vol 6, no. 10, 2018, pp. 70-80. doi: http://dx.doi.org/10.20431/2349-0349.0610006.

Copyright: (c) 2018 Authors. This is an open-access article distributed under the terms of the Creative Commons Attribution License, which permits unrestricted use, distribution, and reproduction in any medium, provided the original author and source are credited. 